(C) 2020, The Authors. Published by Elsevier Inc. and Fass Inc. on behalf of the American Dairy Science Association ${ }^{\circledR}$. This is an open access article under the CC BY-NC-ND license (http://creativecommons.org/licenses/by-nc-nd/4.0/).

\title{
Changes in fluid and acid-base status of diarrheic calves on different oral rehydration regimens
}

\author{
J. Wenge-Dangschat, ${ }^{1}$ I. Steinhöfel, ${ }^{2}$ M. Coenen, ${ }^{1}$ A. Tuchscherer, ${ }^{3}$ H. M. Hammon, ${ }^{3}$ and L. Bachmann ${ }^{3 *}$ \\ ${ }^{1}$ Institute for Animal Nutrition, Nutrition Disease and Dietetics, Faculty of Veterinary Medicine, University of Leipzig, 04109 Leipzig, Germany \\ ${ }^{2}$ Department of Animal Production, Saxon State Office for Environment, Agriculture and Geology, 04886 Köllitsch, Germany \\ ${ }^{3}$ Leibniz Institute for Farm Animal Biology (FBN), 18196 Dummerstorf, Germany
}

\begin{abstract}
The administration of oral rehydration solutions (ORS) is an effective method to treat dehydration and acidosis in calves suffering from diarrhea. The ORS can be prepared in water or milk. The aim of the present study was to elucidate how fluid and acid-base balance change after feeding milk compared with ORS prepared in water or milk to diarrheic calves. Calves $(\mathrm{n}=30)$ with naturally acquired diarrhea were sequentially assigned in a 2:1 ratio to the following pretreatments: milk and water-ORS (pretreatment $1 ; \mathrm{n}=20$ calves) or milk-ORS (pretreatment $2 ; \mathrm{n}=10$ calves), respectively. The assignment was done on the day of diarrhea diagnosis. On d $3 \pm 1$ following assignment to pretreatment group, and after a fasting period of $9 \mathrm{~h}$, diarrheic calves were subjected to the following treatments: $2 \mathrm{~L}$ of milk (pretreatment $1 ; \mathrm{n}=10$ calves), water-ORS (pretreatment $1 ; \mathrm{n}=10$ calves), or milk-ORS (pretreatment 2; $\mathrm{n}=10$ calves). Blood samples were taken before and at several time points until $6 \mathrm{~h}$ after feeding. Plasma protein, osmolality, and electrolytes were determined and a blood gas analysis was performed. Change in plasma volume was calculated according to plasma protein, and water intake during the experimental period was recorded. Plasma volume was increased 30 min after feeding water-ORS or milk but the increase was less pronounced after feeding milk compared with water-ORS. After feeding milk-ORS, no significant increase in plasma volume could be detected. Because of the pretreatment, plasma osmolality was higher in calves fed milk-ORS, but no change in plasma osmolality after feeding was detected. No difference in water consumption between the treatment groups was noted within the observed 6-h period. The $\mathrm{pH}$ was increased after feeding milk-ORS, whereas water-ORS and milkfeeding did not increase $\mathrm{pH}$ in blood. Pretreatment with milk-ORS resulted in higher baseline D-lactate
\end{abstract}

Received January 22, 2020.

Accepted May 25, 2020.

*Corresponding author: bachmann@fbn-dummerstorf.de concentration, but feeding milk-ORS reduced D-lactate values after feeding. In calves with diarrhea, plasma volume increased more quickly and to a greater extent after feeding water-ORS; thus, we recommend treating diarrheic calves with water-ORS before supplying milk. Nevertheless, diarrheic calves need milk to fulfill their energy needs. The administration of ORS in milk combined with free water access is more advisable than feeding milk exclusively because milk has no alkalinizing ability and contains less sodium. However, the effects of milk-ORS feeding on D-lactate levels in diarrheic calves need further elucidation.

Key words: oral rehydration, plasma volume, osmolality, strong ion difference

\section{INTRODUCTION}

Diarrhea is a very common disease of calves in their first weeks of life. Worldwide, most calf mortality is caused by diarrhea (Torsein et al., 2011; Azizzadeh et al., 2012; USDA, 2014). Usually diarrheic calves suffer from dehydration and metabolic acidosis (Hartmann et al., 1997). For animal welfare reasons, every diarrheic calf should be treated promptly to replace fluid and electrolyte losses properly. Diarrheal calves without impaired suckle reflex can easily be provided with electrolytes and buffer substances by administration of oral rehydration solutions (ORS; Doré et al., 2019; Sayers et al., 2016).

The rate of plasma volume expansion and the correction of acid-base disorders are directly driven by the speed of abomasal emptying and the capacity of the absorption of water and electrolytes in the small intestine (Wittek et al., 2005; Nouri and Constable, 2006). When feeding milk or milk replacer, abomasal curd formation is responsible for the prolonged duration of caseins in the abomasum and regulates the flow of fat and protein in the small intestine. Lactose and whey are rapidly expelled from the abomasum and released to the duodenum (Petit et al., 1987). Because feeding milk can help calves with diarrhea reach their energy requirements, the preparation of ORS in milk 
or isotonic milk replacer in combination with free water access offers a simple and timesaving method to treat diarrheic calves when they are fed restrictively via nipple bucket. If calves are fed ad libitum by automatic milk feeder, the permanent provision of ORS prepared in water is appropriate (Wenge et al., 2014). Particularly, ORS containing $\mathrm{HCO}_{3}{ }^{-}$were thought to inhibit abomasal milk clotting (Naylor, 1992). Because of concerns about interference of ORS with abomasal milk clotting, the recommendation was that feeding of milk and ORS should be strictly separated (Rademacher et al., 2002), which is a time-consuming therapy protocol and may explain why diarrheic calves are more often treated with antibiotics instead of adequately provided with ORS (Olson et al., 2019). However, research revealed that ORS with moderate $\mathrm{HCO}_{3}{ }^{-}$levels $(\leq 60 \mathrm{mmol} / \mathrm{L})$ does not prevent milk clotting in the abomasum of healthy calves (Bachmann et al., 2009b; Constable et al., 2009). Milk clotting also occurs in diarrheic calves (Kirchner et al., 2015). Several studies in calves (Nouri and Constable, 2006; Sen et al., 2006; Constable et al., 2009) have revealed that energy density $(\mathrm{kJ} / \mathrm{L})$ is the main factor affecting abomasal emptying. Therefore, abomasal passage of milk, milkbased ORS, and hypertonic ORS in healthy calves is decelerated compared with that of isotonic ORS prepared in water (Bell and Razig, 1973; Constable et al., 2005a; Nouri and Constable, 2006). However, the rate of increasing plasma volume is comparable in healthy calves when feeding either milk- or water-ORS because ORS prepared in milk have higher sodium content, and the absorption of sodium mainly drives the expansion of plasma volume. Hence, delivery of sodium into the duodenum and the absorption of sodium via the duodenal mucosa might be the same per unit time after feeding water-ORS or milk-ORS, although abomasal passage of milk-ORS is delayed (Bachmann et al., 2012). Oral rehydration solutions directly prepared in milk or milk replacer are hypertonic, have higher strong ion difference (SID) values, and, therefore, are more effective in treating dehydration and acidosis (Constable et al., 2005b; Bachmann et al., 2009b; Sayers et al., 2016). However, milk-ORS feeding strictly requires free water access to prevent hypernatremia (Kirchner et al., 2014). Further research has shown that feeding milk or milk-ORS delays abomasal passage in diarrheic calves compared with healthy calves (Kirchner et al., 2015; Hildebrandt et al., 2017). Data on abomasal emptying of isotonic water-ORS in diarrheic calves are currently lacking. The delay in abomasal emptying in diarrheic calves may imply that the correction of fluid and acidbase disorders is decelerated in calves suffering from diarrhea. According to the present research, there are 2 main options for oral rehydration management of diarrheic calves: (1) alternating feeding of milk and water-ORS, or (2) feeding of milk-ORS combined with free water access. That means diarrheic calves receive (1) milk, (2) water-ORS, or (3) milk-ORS at certain feeding time points during a diarrheic episode. Therefore, we were interested how fluid and acid-base status change directly after feeding milk, water-ORS, or milkORS to diarrheic calves and hypothesized that the time course of fluid and acid-base variables differs among the different treatments.

\section{MATERIALS AND METHODS}

All experimental procedures were conducted in accordance with the German Animal Welfare Act and were approved by federal authorities for animal research (Landesdirektion Leipzig, Germany, A18/12).

\section{Animals}

Thirty Holstein-Friesian calves (17 male and 13 female) born at Köllitsch (Farm for Teaching and Research of the Department of Animal Production of the Saxon State Office for Environment, Agriculture and Geology, Köllitsch, Germany) were used in the study and housed in calf hutches with straw bedding. Before the occurrence of diarrhea, calves were fed $2 \mathrm{~L}$ of warm cow milk $\left(38^{\circ} \mathrm{C}\right) 3$ times per day $(0700,1600$, and 2200 h). Calves had free access to water and were provided with hay and concentrates. Every morning, calves were clinically examined, and the fecal consistency (scored from 1 to 4 where $1=$ pasty, $2=$ pulpy, $3=$ soupy, $4=$ watery; Groutides and Michell, 1990) of each calf was recorded. Calves with fecal consistency 3 or 4 were classified as having diarrhea. Usually diarrhea started at $d$ $8( \pm 0.26)$ after birth. After occurrence of diarrhea, a fecal sample was collected and analyzed microscopically for Cryptosporidium parvum oocysts according to Heine (1982). Additionally, a rapid sandwich-immunoassay (BioDa, Fassisi, Göttingen, Germany) was used to detect rotavirus, coronavirus, Escherichia coli (K99), and Cryptosporidium parvum. According to the manufacturer, sensitivity and specificity of this test are between 88.89 and $99.99 \%$ for all pathogens (Fassisi, 2020).

\section{Experimental Design}

Pretreatment Period. In the case of diarrhea, calves were allocated sequentially in a 2:1 ratio to one of the following oral rehydration pretreatments: one group received ORS prepared in $2 \mathrm{~L}$ of water (water-ORS) $2 \mathrm{~h}$ after feeding of the milk ration 3 times a day $(20$ calves, pretreatment 1) and the other group received ORS prepared in $2 \mathrm{~L}$ of milk (milk-ORS) 3 times a 
day (10 calves, pretreatment 2). Randomization was done in chronological order of occurrence of diarrhea; calves were not blocked for sex or other characteristics. Every calf was offered the same amount of milk $(6 \mathrm{~L} / \mathrm{d})$ and ORS product $(225 \mathrm{~g} / \mathrm{d})$. When the calves had not ingested their milk or ORS ration they were encouraged to drink by leading them to the nipple. Calves were not tube-fed. Intakes of milk and ORS were monitored before experimental period. Monitoring intakes on the day before experimental feedings was crucial for decision of starting experiments. The calves were not treated with any options (e.g., antibiotics or nonsteroidal anti-inflammatory drugs) other than ORS.

Treatment Period. Experiments started on d $3 \pm 1$ after the onset of diarrheic disease (age of calves $11 \pm$ $1 \mathrm{~d})$. Calves were included in the experiments if diarrhea had lasted $>24 \mathrm{~h}$ and if they had sufficient suckle reflex. The experimental period per day consisted of 6 h $(0700$ to $1300 \mathrm{~h})$. Before the start of the experiments, the calves were clinically examined and weighed, and the degree of dehydration was scored according to eye position within the orbital cavity and skin elasticity on a scale from 0 to $3(0=$ normal; $1=$ eyes beginning to sink/decreased skin turgor; $2=$ eyes sunken/mucous membranes tacky; or $3=$ eyes deeply sunken/skin tent $>5$ s; Goodell et al., 2012). Each calf was fitted with an indwelling catheter in the jugular vein, secured in place with suture material. After a fasting period of 9 $\mathrm{h}$, calves (10 per group) were fed with $2 \mathrm{~L}$ of (1) milk (following pretreatment 1), (2) water-ORS (following pretreatment 1), or (3) milk-ORS (following pretreatment 2) and deprived of hay and concentrates. Calves of the pretreatment 1 group were randomly allocated to experimental feeding of water-ORS or milk. Randomization was achieved by sequence in chronological order of enrollment. Julia Wenge-Dangschat and Lisa Bachmann were responsible for randomization, treatments, and blood sampling and thus were not blinded to the group assignments. Calves had free access to water, and water intake was recorded during the feeding experiments. Each calf received a bucket with $5 \mathrm{~L}$ of fresh water in its box, which was weighed before and after experiments. To calculate evaporation of water from the bucket, an additional bucket was placed in the middle of the area where the calves were housed and weighed after experimental period. Water intake of a calf was calculated as the difference in weight of the bucket of each calf minus evaporation. Blood samples were taken via jugular catheter before and 15 , $30,45,60,90,120,180,240$, and 360 min after feeding. At the end of the experimental period $(1300 \mathrm{~h})$, vein catheters were removed, calves had free access to hay and concentrate again, and calves that received milk or water-ORS for experimental feeding were administered either water-ORS or milk to ensure electrolyte or energy supply, respectively. Osmolality was measured and $\left[\mathrm{Na}^{+}\right],\left[\mathrm{K}^{+}\right],\left[\mathrm{Cl}^{-}\right]$, and $\mathrm{SID}\left(\left[\mathrm{SID}_{3}\right] \mathrm{mmol} / \mathrm{L}=\left[\mathrm{Na}^{+}\right]\right.$ $\left.+\left[\mathrm{K}^{+}\right]-\left[\mathrm{Cl}^{-}\right]\right)$in the different feeding regimens were calculated according to the specifications of the manufacturer of the ORS (Lytafit, Albrecht GmbH, Aulendorf, Germany) and according to Gaucheron (2005) for milk electrolytes, respectively (Table 1). The ORS product had an $\left[\mathrm{HCO}_{3}{ }^{-}\right]$of $62 \mathrm{mmol} / \mathrm{L}$, and included lactose, glycine, $\mathrm{Ca}^{2+}$, and $\mathrm{Mg}^{2+}$. The ORS product was not labeled to add to milk but it was previously demonstrated to not interfere with milk clotting in the abomasum of healthy (Bachmann et al., 2009a) and diarrheic calves (Kirchner et al., 2015).

Sample Size. The experimental design for the tests of the treatment effects in the ANOVA model was carried out using corresponding ANOVA $F$-tests. The required number of animals per treatment group was calculated using PROC POWER of SAS software (version 9.4; SAS Institute Inc., Cary, NC), with the specification of $\alpha=0.05$ and $\beta_{0}=0.20$, and a minimum difference of the treatment group level $d$ to be detected, which was chosen as a relative $c$-fold of the residual standard deviation $\sigma(d=c \times \sigma)$. Because of the relative specification of the minimum difference $d, \sigma^{2}=1$ had to be set in the program. To detect differences of at least 1.5 residual standard deviations between the treatment group levels, 10 animals for each level were required; that is, a total of 30 animals. If the minimum difference $d$ was chosen as a relative $c$-fold of the residual standard deviation $\sigma(d=c \times \sigma)$, we get the same relative accuracy for each trait. For example, one of the most

Table 1. Composition of experimental treatments of milk, oral rehydration solution prepared in water (waterORS), and ORS prepared in milk (milk-ORS) ${ }^{1}$

\begin{tabular}{lccccc}
\hline Treatment & $\begin{array}{c}\text { Osmolality } \\
(\mathrm{mOsm} / \mathrm{L})\end{array}$ & $\begin{array}{c}{\left[\mathrm{Na}^{+}\right]} \\
(\mathrm{mmol} / \mathrm{L})\end{array}$ & $\begin{array}{c}{\left[\mathrm{K}^{+}\right]} \\
(\mathrm{mmol} / \mathrm{L})\end{array}$ & $\begin{array}{c}{\left[\mathrm{Cl}^{-}\right]} \\
(\mathrm{mmol} / \mathrm{L})\end{array}$ & $\begin{array}{c}{\left[\mathrm{SID}_{3}\right]} \\
(\mathrm{mmol} / \mathrm{L})\end{array}$ \\
\hline Milk & 290 & 25 & 40 & 30 & 35 \\
Water-ORS & 365 & 81 & 13 & 45 & 49 \\
Milk-ORS & 655 & 106 & 53 & 75 & 84 \\
\hline
\end{tabular}

${ }^{1}$ Osmolality (measured); $\left[\mathrm{Na}^{+}\right],\left[\mathrm{K}^{+}\right],\left[\mathrm{Cl}^{-}\right]$according to Gaucheron (2005) for milk and according to the specifications of the manufacturer for the ORS; and strong ion difference, where $\left[\mathrm{SID}_{3}\right]=\left[\mathrm{Na}^{+}\right]+\left[\mathrm{K}^{+}\right]-\left[\mathrm{Cl}^{-}\right]$. 
relevant variables to consider in calf diarrhea is blood $\mathrm{pH}$. Based on the outcome of previous studies dealing with ORS efficacy in healthy (Bachmann et al., 2012) and experimentally dehydrated calves (Kirchner et al., 2014), the estimated standard deviation for blood $\mathrm{pH}$ was 0.03 . With $\sigma_{\mathrm{pH}}=0.03$ and $c=1.5$, the minimum $\mathrm{pH}$ difference that could be detected is $d_{\mathrm{pH}}=0.045$.

\section{Measurements and Analyses}

Blood gas analysis, including $\left[\mathrm{Na}^{+}\right],\left[\mathrm{K}^{+}\right],\left[\mathrm{Cl}^{-}\right]$, and hematocrit (ABL 80 Flex, Radiometer, Copenhagen, Denmark), was carried out directly after blood sampling before and after administration of experimental diets. Plasma D- and L-lactate concentrations were also measured before and after feeding, and samples in vials containing sodium fluoride were analyzed enzymatically using D- and L-lactate dehydrogenase. After centrifugation $(2,000 \times g, 10 \mathrm{~min})$, plasma samples were frozen $\left(-20^{\circ} \mathrm{C}\right)$ until measurement of total plasma protein (Hitachi 912, Boehringer, Mannheim, Germany; biuret method) and osmolality (Osmometer K-7400, Knauer, Berlin, Germany; freezing point depression method). The calculated change in plasma volume after feeding was assessed from the plasma protein concentration before feeding $\left(\mathbf{P}_{\mathbf{t}=0}\right)$ and plasma protein concentration after feeding $\left(\mathbf{P}_{\mathrm{t}=\mathrm{x}}\right)=\left(\mathrm{P}_{\mathrm{t}=0}-\mathrm{P}_{\mathrm{t}=\mathrm{x}}\right) \times 100 / \mathrm{P}_{\mathrm{t}=\mathrm{x}}($ Van Beaumont et al., 1972). Based on the concentrations of total protein in plasma and electrolytes in blood, acid total $\left[\mathbf{A}_{\text {tot }}\right](\mathrm{mmol} / \mathrm{L})=0.343(\mathrm{mmol} / \mathrm{g}) \times$ plasma protein concentration $(\mathrm{g} / \mathrm{L})$ and $\left[\mathrm{SID}_{3}\right]$ were calculated (Constable et al., 2005b).

\section{Statistical Analyses}

Data were expressed as least squares means \pm standard errors (LSM $\pm \mathrm{SE}$ ) and analyzed by repeatedmeasures ANOVA using the MIXED procedure of SAS (version 9.4, 2013; SAS Institute Inc.) with treatment group (pretreatment $1+$ milk, pretreatment $1+$ waterORS, and pretreatment $2+$ milk-ORS), time (baseline, $+15,+30,+45,+60,+90,+120,+180,+240$, and +360 min), sex, and all interactions of treatment, time, and sex as fixed effects. Time was the repeated variable, and an unstructured type of the block diagonal residual covariance matrix was used. Pairwise differences of LSM were tested using the Tukey-Kramer procedure. Partitioned analyses of treatment by time interactions were done using the SLICE statement of the MIXED procedure. The effects of pretreatment on baseline values (time $=$ baseline) were tested separately in the mixed model and the recorded water intakes of the calves during the experimental period were compared by one-way ANOVA. Pearson product-moment correlation coefficients $(\mathrm{r})$ were calculated between partial pressure of $\mathrm{CO}_{2}\left(\mathbf{p C O}_{2}\right),\left[\mathrm{SID}_{3}\right],\left[\mathrm{A}_{\text {tot }}\right]$, [D-lactate], [L-lactate], and $\mathrm{pH}$ in blood with the CORR procedure of SAS to display the associations of these parameters with blood $\mathrm{pH}$.

\section{RESULTS}

All animals tested positive for C. parvum and were negative for rotavirus, coronavirus, and E. coli. The rations of $6 \mathrm{~L}$ of milk and $225 \mathrm{~g}$ of ORS were not fully ingested by the calves before experiments (Table 2). Clinical score of dehydration revealed that most of the calves had a dehydration score of 0 or 1 and no calf had a dehydration score $>2$, suggesting the calves were only mildly to moderately dehydrated (values of clinical examination are shown also shown in Table 2). No animals died due to diarrhea after the experimental period.

\section{Fluid Status}

Plasma volume was increased 30 min after feeding water-ORS $(P=0.004)$ and milk $(P=0.04)$. The rate of increasing plasma volume was not different, but the expansion of plasma volume was less pronounced after feeding milk compared with water-ORS (Figure 1A). After feeding milk-ORS, no significant increase of plasma volume was detected within the experimental period of $6 \mathrm{~h}$; however, plasma volume tended to be increased 60 min after administration of milk-ORS $(P=0.09)$. Because the change in plasma volume was calculated from plasma protein, total plasma protein showed the same pattern as expansion of plasma volume (Table 3 ).

We observed a pretreatment effect on baseline values of plasma osmolality $(P=0.02)$. Plasma osmolality was higher in milk-ORS calves at baseline $(P=0.01)$ and after feeding (15 min: $P=0.004,30$ min: $P=0.06,45$ min: $P=0.02,60 \mathrm{~min}: P=0.005,90 \mathrm{~min}: P=0.005,120$ min: $P=0.02,180 \mathrm{~min}: P=0.01,240 \mathrm{~min}: P=0.005$, 360 min: $P=0.002$ ) compared with milk-fed calves. At baseline, plasma osmolality in water-ORS group was not different from milk or milk-ORS calves $(P=0.29)$. However, at several time points after feeding, plasma osmolality was higher in water-ORS than in milk-fed calves (60 min: $P=0.03,240 \mathrm{~min}: P=0.04,360 \mathrm{~min}$ : $P=0.04)$, whereas there were no statistical differences between the water-ORS and milk-ORS group (Figure 1B). The concentration of $\mathrm{Na}^{+}$was higher in milk- and water-ORS calves compared with milk-fed calves (Figure 1C). Numerically, there was an increase in $\left[\mathrm{Na}^{+}\right]$ in milk- and water-ORS calves after feeding, whereas $\left[\mathrm{Na}^{+}\right]$decreased in milk-fed calves. Hematocrit declined at $30(P=0.007)$ and $45 \mathrm{~min}(P=0.01)$ after feed- 


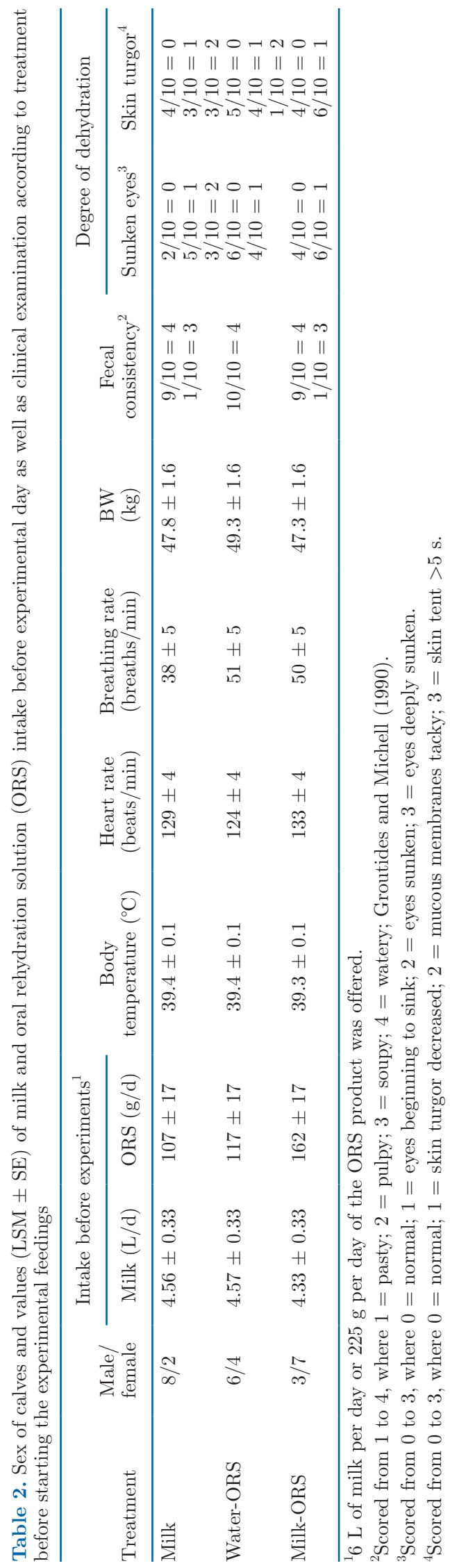

A

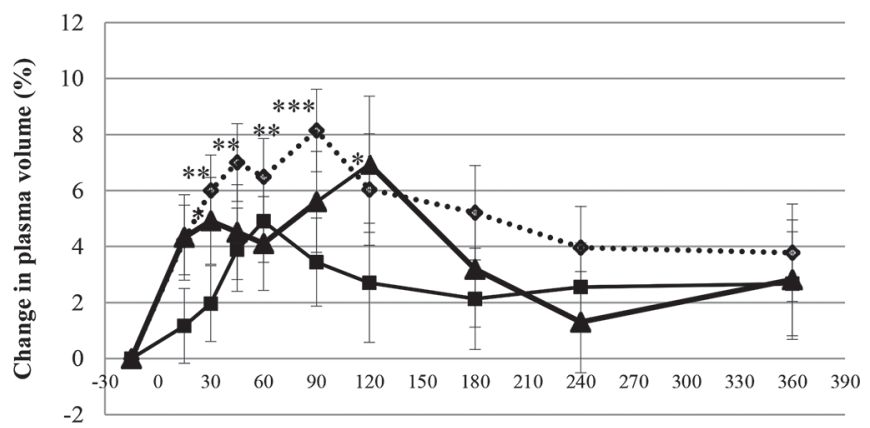

B

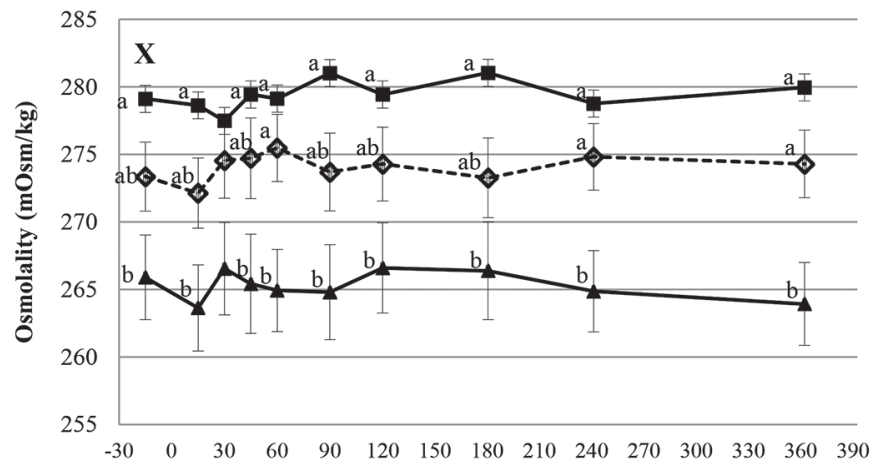

C

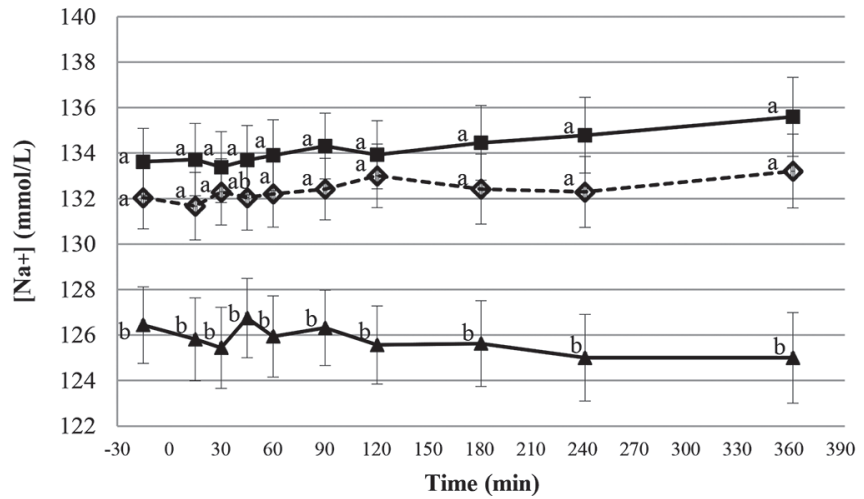

Figure 1. (A) Calculated change in plasma volume, (B) plasma osmolality, and $\left.(\mathrm{C}) \mathrm{Na}^{+}\right]$in blood after feeding milk, oral rehydration solution prepared in water (water-ORS), or oral rehydration solution prepared in milk (milk-ORS). Data are presented as LSM \pm SE. Asterisks indicate statistically significant differences from baseline $\left({ }^{*} P<0.05 ;{ }^{* *} P<0.01 ;{ }^{* * *} P<0.001\right)$. Lowercase letters indicate statistically significant differences between treatments $(P<0.05)$. X indicates significant differences between baseline values according to pretreatment 1 and $2(P=0.02)$. Statistically significant effects for change in plasma volume: time $(P<0.001)$, time $\times$ treatment $(P=$ $0.02)$, time $\times$ treatment $\times \operatorname{sex}(P=0.007)$. Statistically significant effects for plasma osmolality: treatment $(P=0.007)$, treatment $\times$ sex $(P$ $=0.03)$, time $\times$ treatment $\times \operatorname{sex}(P=0.01)$. Statistically significant effects for $\left[\mathrm{Na}^{+}\right]$in blood: treatment $(P=0.004)$, sex $(P=0.03)$, time $\times$ treatment $(P=0.03)$, treatment $\times \operatorname{sex}(P=0.008)$. 
Wenge-Dangschat et al.: ORAL REHYDRATION THERAPY IN DIARRHEIC CALVES

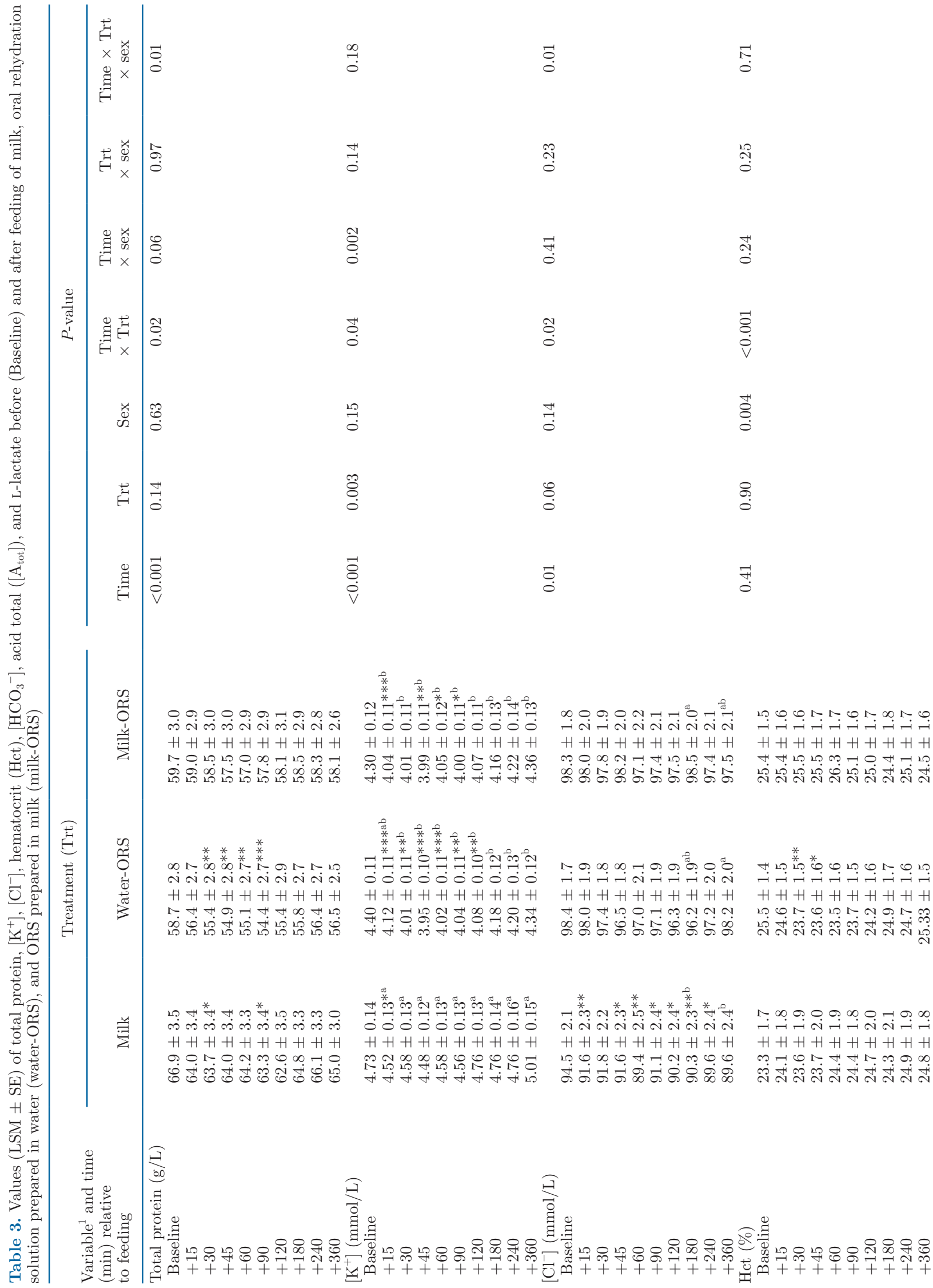


Wenge-Dangschat et al.: ORAL REHYDRATION THERAPY IN DIARRHEIC CALVES

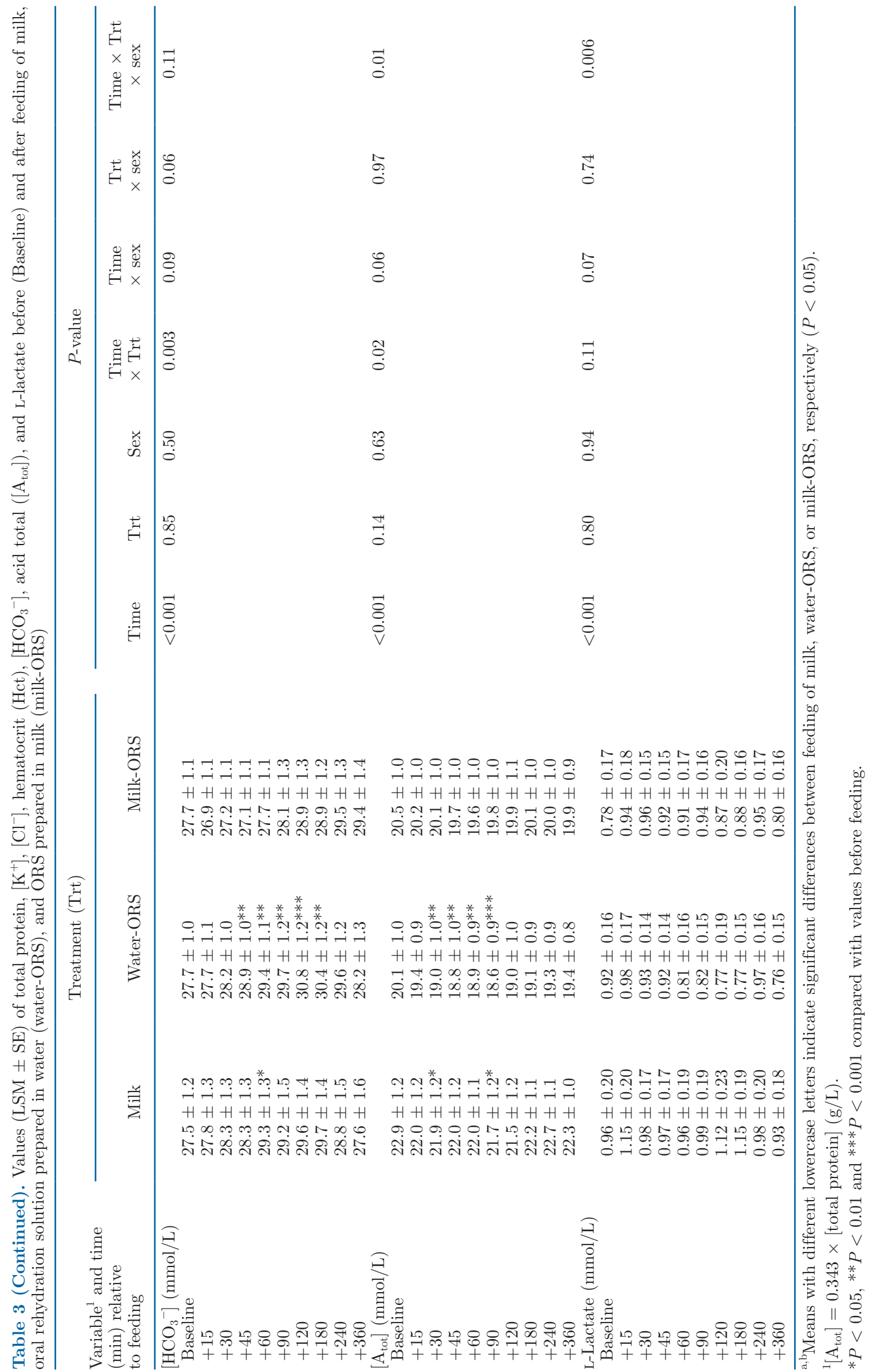




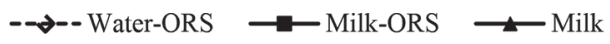

A

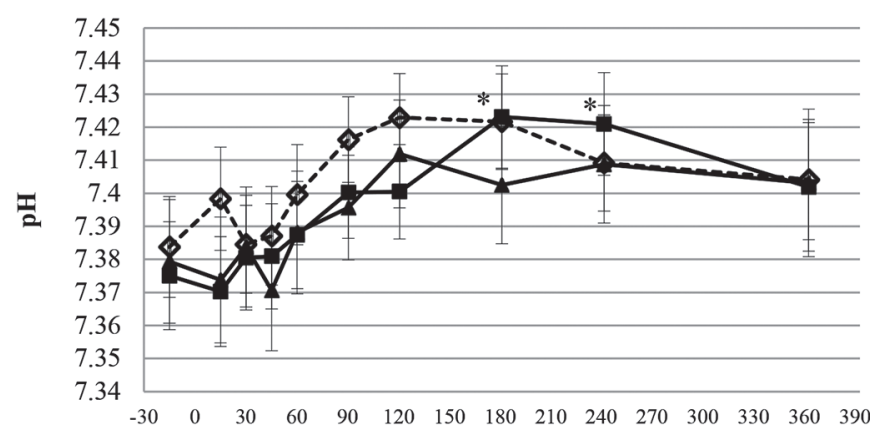

B

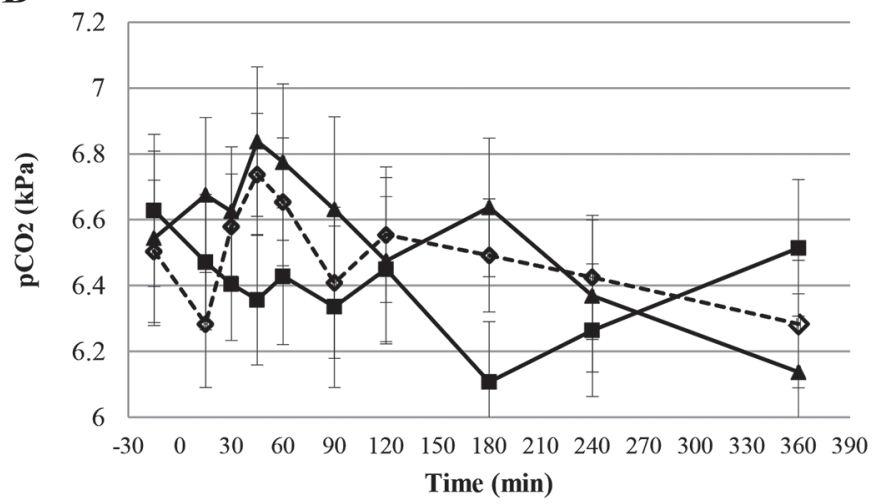

C

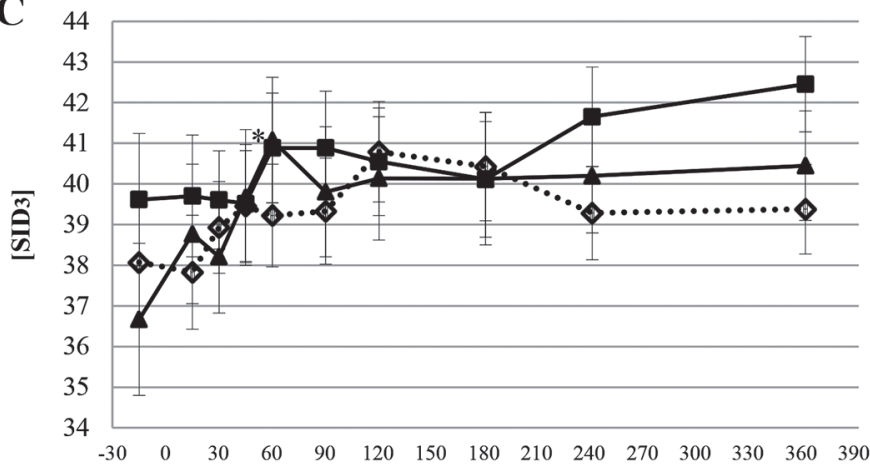

D

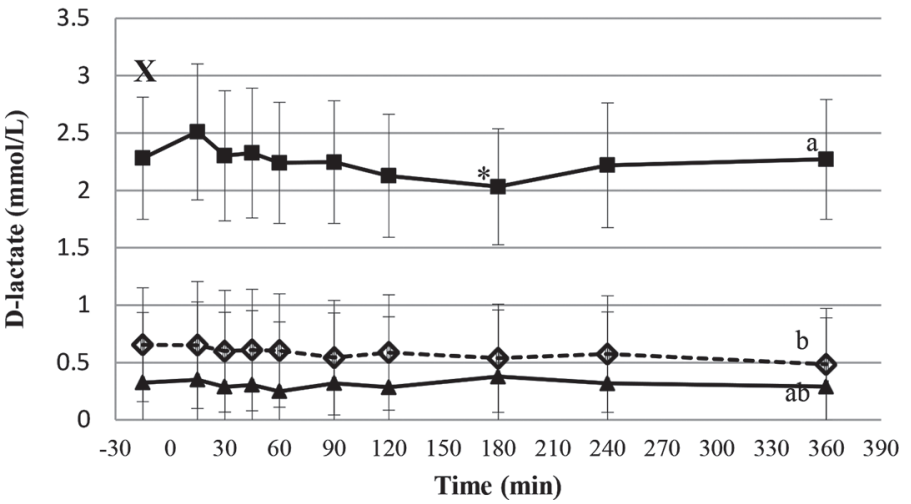

Figure 2. (A) Venous $\mathrm{pH},(\mathrm{B})$ partial pressure of $\mathrm{CO}_{2}\left(\mathrm{pCO}_{2}\right),(\mathrm{C})$ strong ion difference $\left(\mathrm{SID}_{3}\right)$, and (D) concentration of D-lactate after feeding milk, oral rehydration solution prepared in water (water-ORS), or oral rehydration solution prepared in milk (milk-ORS) in 30 experiments. Data are presented as LSM \pm SE. Asterisks indicate statistically significant differences from baseline $(* P<0.05)$. Lowercase letters (a, b) indicate statistically significant differences between feeding regimens $(P<0.05)$. X indicates significant differences between baseline values according to pretreatment 1 and $2(P=0.008)$. Statistically significant effects for venous $\mathrm{pH}$ : time $(P<0.001)$, time $\times$ sex $(P=0.045)$. Statistically significant effects for $\mathrm{pCO}_{2}$ : time $\times \operatorname{sex}(P=0.01)$, treatment $\times \operatorname{sex}(P=0.002)$, time $\times$ treatment $\times$ sex $(P<0.001)$. Statistically significant effects for $\left[\mathrm{SID}_{3}\right]$ : time $(P=0.04)$, time $\times$ treatment $(P=0.02)$, time $\times$ treatment $\times \operatorname{sex}(P=0.01)$. Statistically significant effects for [D-lactate]: time $(P<0.001)$, treatment $(P=0.04)$, time $\times$ treatment $(P<0.001)$, time $\times \operatorname{sex}(P<0.001)$, time $\times$ treatment $\times$ sex $(P=0.02)$.

ing water-ORS and remained unchanged in the other groups (Table 2). Interestingly, we observed an effect of sex on hematocrit as well as on $\left[\mathrm{Na}^{+}\right]$.

The recorded water intake during the experimental period did not differ between the treatment groups $(P$ $=0.70$; water intake: milk $=0.9 \pm 0.6 \mathrm{~L}$; water-ORS $=$ $0.7 \pm 0.4 \mathrm{~L} ;$ milk-ORS $=0.9 \pm 0.7 \mathrm{~L})$.

\section{Acid-Base Status}

Each feeding group contained an acidotic calf (blood $\mathrm{pH}<7.30$ ) before feeding of treatments. All other calves had fasting $\mathrm{pH}$ values $\geq 7.34$. Blood $\mathrm{pH}$ increased 180 $(P=0.05)$ and $240 \mathrm{~min}(P=0.02)$ after administration of milk-ORS. Milk and water-ORS feeding did not affect blood $\mathrm{pH}$ (Figure $2 \mathrm{~A}$ ). The $\mathrm{pCO}_{2}$ remained nearly constant in all feeding groups $\left(P_{\text {time }}=0.16\right.$; Figure 2B). The concentration of $\mathrm{HCO}_{3}{ }^{-}$increased between
60 and 180 min after feeding water-ORS and $60 \mathrm{~min}$ after feeding milk (Table 3). Although $\left[\mathrm{Na}^{+}\right]$decreased in milk-fed calves, $\left[\mathrm{SID}_{3}\right]$ increased 60 min after feeding $(P=0.02$; Figure $2 \mathrm{C})$. The rise in $\left[\mathrm{SID}_{3}\right]$ after administration of milk was due to a significant decrease in $\left[\mathrm{Cl}^{-}\right](P=0.005$; Table 3$)$. Compared with baseline values, $\left[\mathrm{Cl}^{-}\right]$was diminished several times after milk feeding and $\left[\mathrm{Cl}^{-}\right]$in milk-fed calves was lower than in milk-ORS calves $180 \mathrm{~min}(P=0.03)$ or in waterORS calves $360 \mathrm{~min}(P=0.03)$ after feeding. The concentration of $\mathrm{K}^{+}$decreased in all groups, reaching significance at several time points (Table 3 ). Because $\left[\mathrm{A}_{\text {tot }}\right]$ was calculated from total protein, it showed the same pattern after feeding (Table 3). A pretreatment effect on baseline values of D-lactate could be detected. D-Lactate was higher in milk-ORS pretreated calves $(P$ $=0.008)$. After feeding milk-ORS, D-lactate decreased, reaching significance $180 \mathrm{~min}$ after feeding $(P=0.04)$. 
However, $360 \mathrm{~min}$ after feeding, D-lactate was higher in milk-ORS calves than in calves fed with water-ORS $(P=0.05$; Figure 2D). L-Lactate did not differ among feeding regimens (Table 3 ).

Blood $\mathrm{pH}$ was negatively correlated with $\mathrm{pCO}_{2}$ and $\left[\mathrm{A}_{\text {tot }}\right]$ (Figure 3A and $\mathrm{B}, \mathrm{r}=-0.17, P=0.003$ and $\mathrm{r}=$ $-0.15, P=0.007$, respectively), whereas there was no correlation of $\left[\mathrm{SID}_{3}\right]$ and blood $\mathrm{pH}$ (Figure $3 \mathrm{C}, \mathrm{r}=0.02$, $P=0.7)$. The strongest relationship was detected be- tween D-lactate and blood $\mathrm{pH}$ (Figure 3D, $\mathrm{r}=-0.39, P$ $<0.001)$. Interestingly, in the group of calves with low $\mathrm{pH}$ values, 2 calves had high values for D-lactate $(>4$ $\mathrm{mmol} / \mathrm{L}$ in water-ORS and $>8 \mathrm{mmol} / \mathrm{L}$ in milk-ORS), whereas 1 calf with acidosis had D-lactate values $<0.1$ $\mathrm{mmol} / \mathrm{L}$ but low $\left[\mathrm{SID}_{3}\right]$ values $(32.2 \mathrm{mmol} / \mathrm{L}$ in milkfeeding group) due to hyponatremia (126 mmol/L). There was no association between L-lactate and $\mathrm{pH}$ (Figure 3E, $\mathrm{r}=0.05, P=0.4$ ).
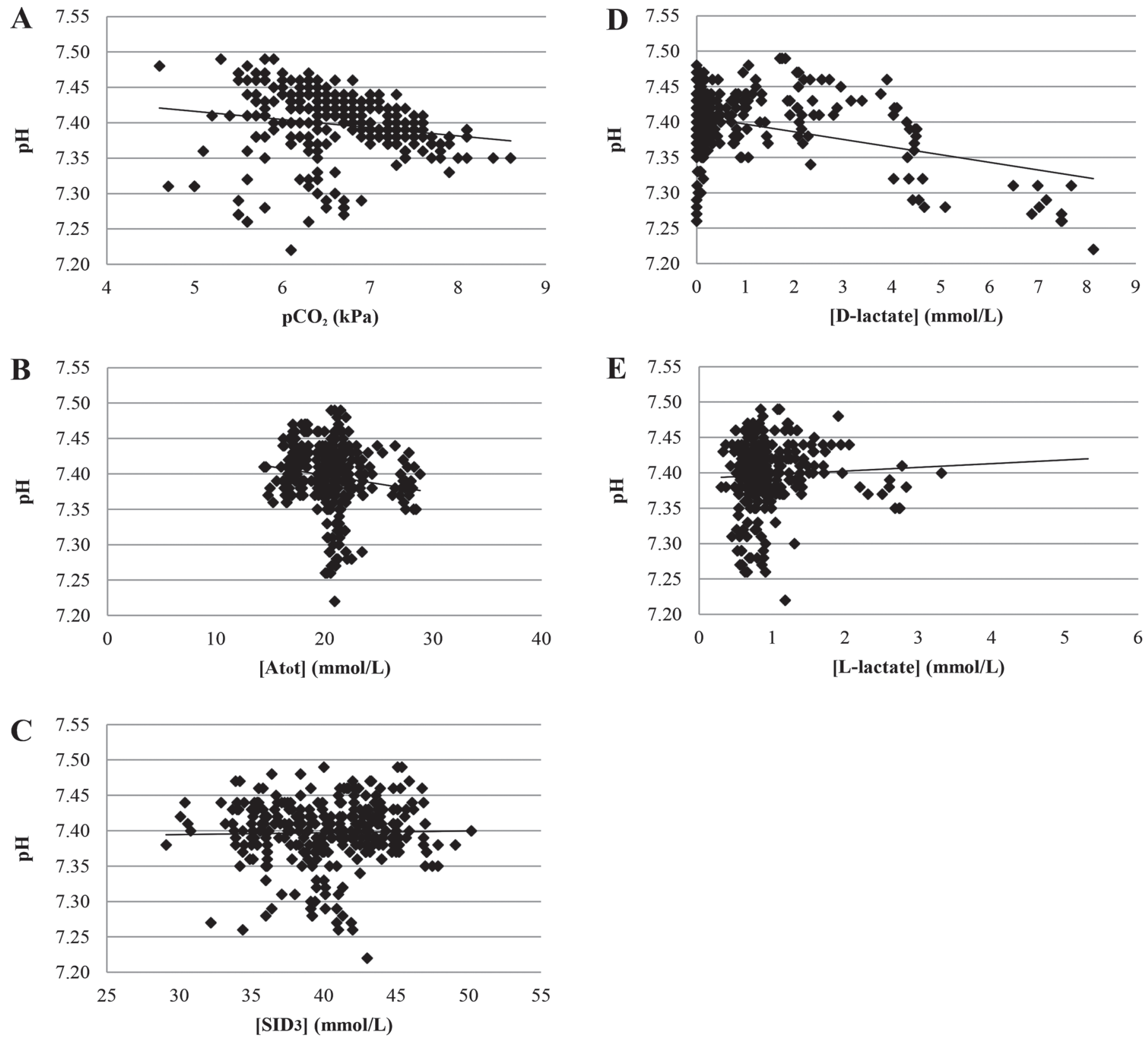

Figure 3. Scatterplots of the correlation between venous $\mathrm{pH}$ and $(\mathrm{A})$ partial pressure of $\mathrm{CO}_{2}\left(\mathrm{pCO}_{2}, \mathrm{r}=-0.17, P=0.003\right)$, (B) acid total $\left(\left[\mathrm{A}_{\text {tot }}\right], \mathrm{r}=-0.15, P=0.007\right),(\mathrm{C})$ strong ion difference $\left(\left[\mathrm{SID}_{3}\right], \mathrm{r}=0.02, P=0.7\right),(\mathrm{D})$ D-lactate $(\mathrm{r}=-0.39, P<0.001)$, and $(\mathrm{E}) \mathrm{L}-\mathrm{lactate}(\mathrm{r}$ $=0.05, P=0.4$ ), respectively. Solid line = linear trend line. 


\section{DISCUSSION}

\section{Fluid Status}

The administration of ORS remains the gold standard for resuscitating diarrheic calves with moderate dehydration and acidemia (Taylor et al., 2017; Doré et al., 2019). Worldwide, diarrhea caused by C. parvum is one of the most important diseases of young ruminant livestock, particularly in neonatal calves. The parasite invades epithelial cells of the ileum. Infection with $C$. parvum leads to malabsorption with profuse watery diarrhea. Unfortunately, relatively few tools are available to combat bovine cryptosporidiosis (Thomson et al., 2017), and the most important factor in treating cryptosporidiosis is to compensate fluid and electrolyte losses.

In the present experiments, we observed that plasma volume only tended to increase with administration of milk-ORS, suggesting that hypertonic milk-ORS is not able to increase plasma volume rapidly like waterORS or milk in calves with naturally acquired diarrhea. Jones et al. (1984) reported a slight increase in plasma protein concentration $15 \mathrm{~min}$ after feeding a hypertonic ORS to diarrheic calves, indicating a decrease in plasma volume. However, in that study, the values of plasma protein were already lower than before feeding at $45 \mathrm{~min}$ after feeding. We observed no measurable decline in plasma volume after feeding hypertonic ORS, which agrees with Kirchner et al. (2014) and previous studies (Levy et al., 1990; Nouri and Constable, 2006; Bachmann et al., 2009b, 2012). Additionally, it has been shown that hypertonic ORS produce a larger and more sustained increase in plasma glucose concentration (Levy et al., 1990; Nouri and Constable, 2006). Unfortunately, we did not measure plasma glucose in our experiment.

The differences in expanding plasma volume could also be due to different pretreatments of milk and water-ORS versus milk-ORS. We observed an effect of pretreatment on plasma osmolality; that is, plasma osmolality was higher in calves pretreated with milkORS. The higher osmolality in calves fed milk-ORS could have biased the time course of plasma volume expansion. However, at several time points after feeding, plasma osmolality in water-ORS calves was higher than that of milk-fed calves, pointing to positive effects of ORS feeding on plasma osmolality in general. Diarrheic calves usually suffer from hypotonic or isotonic dehydration (Fayet, 1971). Therefore, an increase in plasma osmolality is a desirable effect of ORS treatment. Hypernatremia occurs in calves dying from diarrhea because of renal failure (Hartmann et al., 1983). In healthy calves, plasma osmolality remains constant after feeding hypertonic ORS because mean total body water is not impaired and water can be distributed to the plasma space to maintain plasma osmolality (Bachmann et al., 2012). In experimentally dehydrated calves, hypertonic milk-ORS elevate plasma osmolality, an effect that can antagonize dehydration if water is freely available (Kirchner et al., 2014; Wenge et al., 2014). Without free water access, acute hypernatremia might be the consequence when dehydrated calves are treated with hypertonic ORS (Kirchner et al., 2014; Trefz et al., 2017). In a recent study in calves with osmotic diarrhea, a slightly hypertonic ORS, alone and combined with intravenous hypertonic saline infusion, was superior in expanding plasma volume compared with intravenous Ringer lactate infusion (Doré et al., 2019). The increase in plasma osmolality, in particular $\left[\mathrm{Na}^{+}\right]$, causes thirst and leads to higher consumption of water (Sen et al., 2009; Thornton, 2010; Wenge et al., 2014). Despite higher plasma osmolality and $\left[\mathrm{Na}^{+}\right]$in the milk-ORS group compared with milk-fed calves, water intake did not differ between the feeding regimens during the observation period of $6 \mathrm{~h}$, which disagrees with our previous results that diarrheic calves fed milk-ORS consumed more water per day (Wenge et al., 2014). However, in the present study, $\left[\mathrm{Na}^{+}\right]$was also higher in water-ORS calves, and $\left[\mathrm{Na}^{+}\right]$increased numerically but not significantly.

The differences in expanding plasma volume cannot be explained by different abomasal flow rates of the feeding regimens because milk and water-ORS expanded plasma volume at equal rates. As such, pretreatment effects and individual effects of diarrheic disease on plasma protein and volume, plasma osmolality, and gut integrity could have biased the results, because the conditions in diarrheic calves obviously cannot be standardized. Moreover, some baseline values, particularly $\left[\mathrm{Na}^{+}\right]$, were quite different between water-ORS and milk-fed calves, although they had the same pretreatment and consumed comparable amounts of milk and water-ORS before treatment experiments, which points to a high individual influence on treatment effects. Therefore, more research on oral rehydration management under different conditions is necessary to improve treatment of diarrheic calves.

\section{Acid-Base Status}

Acid-base balance in calves can be evaluated by the traditional Henderson-Hasselbalch equation or by the Stewart approach (Constable et al., 2005b). The SID is the main factor in evaluating the alkalinity of an ORS, and ORS that are highly effective in treating diarrheal acidosis have high SID values (Constable 
et al., 2005b; Bachmann et al., 2009b; Sayers et al., 2016). In healthy calves, no effects of ORS supply on traditional parameters of acid-base status $\left(\mathrm{pH}, \mathrm{pCO}_{2}\right.$, and $\mathrm{HCO}_{3}{ }^{-}$) could be detected, but they did affect the Stewart parameters $\mathrm{A}_{\text {tot }}$ and $\mathrm{SID}_{3}$. Previous research noted a decrease in $\left[A_{\text {tot }}\right]$ after feeding milk, waterORS, and milk-ORS and an increase in $\left[\mathrm{SID}_{3}\right]$ when feeding ORS with $\left[\mathrm{SID}_{3}\right]>80 \mathrm{mmol} / \mathrm{L}$ to healthy calves (Bachmann et al., 2009b, 2012). Furthermore, a high negative correlation between $\mathrm{pCO}_{2}$ and blood $\mathrm{pH}$ exists in healthy calves (Bachmann et al., 2012). In diarrheic calves in the present study, we observed effects of diet, particularly after water- and milk-ORS administration, on traditional as well as on Stewart parameters. Specifically, $\left[\mathrm{HCO}_{3}{ }^{-}\right]$increased after milk and water-ORS feeding; $\mathrm{pH}$ only increased after milk-ORS feeding. Due to a decrease of $\left[\mathrm{Cl}^{-}\right]$below reference values (Moritz, 2013), $\left[\mathrm{SID}_{3}\right]$ increased after milk feeding. Furthermore, $\left[\mathrm{A}_{\text {tot }}\right]$ decreased in calves fed milk and water-ORS in conjunction with the increase in plasma volume. However, only milk-ORS containing the highest $\left[\mathrm{SID}_{3}\right]$ value $(84 \mathrm{mmol} / \mathrm{L})$ increased $\mathrm{pH}$. That ORS with high $\left[\mathrm{SID}_{3}\right]$ values $(>70 \mathrm{mmol} / \mathrm{L})$ are more effective in increasing $\mathrm{pH}$ in diarrheic calves is consistent with other studies in diarrheic calves evaluated by Constable et al. (2005b).

In general, diarrheic disease affected acid-base balance. Three calves had $\mathrm{pH}$ values below the normal range (Moritz, 2013) and also had decreased $\mathrm{pCO}_{2}$. Because of electrolyte losses, $\left[\mathrm{SID}_{3}\right]$ was diminished in all diarrheic calves compared with reference values of calves of the same age given by Bachmann et al. (2009a). However, calves pretreated with milk-ORS had slightly higher baseline $\left[\mathrm{SID}_{3}\right]$ than calves fed milk and water-ORS, which underlines the effectiveness of ORS with high $\left[\mathrm{SID}_{3}\right]$. This supports a recent study that tested an ORS with $\left[\mathrm{SID}_{3}\right]>100 \mathrm{mmol} / \mathrm{L}$ (Sayers et al., 2016). Due to adequate treatment with ORS before the experimental period, the extent of dehydration was not enough to affect total protein concentration; therefore, $\left[\mathrm{A}_{\text {tot }}\right]$ was equal to that of healthy calves (Bachmann et al., 2009a). However, the correlation of $\left[\mathrm{A}_{\text {tot }}\right]$ and $\mathrm{pH}$ was higher in diarrheic than in healthy calves (Bachmann et al., 2012). In contrast to healthy calves, $\mathrm{pCO}_{2}$ was correlated to a lesser extent with $\mathrm{pH}$ in diarrheic calves, likely because of low $\mathrm{pCO}_{2}$ in calves with acidotic $\mathrm{pH}$ values. Respiratory compensation; that is, increased aspiration of $\mathrm{CO}_{2}$, is a common phenomenon to improve $\mathrm{pH}$ balance in diarrheic calves with metabolic acidosis (Berchtold et al., 2000). Surprisingly, $\left[\mathrm{SID}_{3}\right]$ did not correlate with $\mathrm{pH}$, although $\left[\mathrm{SID}_{3}\right]$ was affected by diarrheic disease, and a correlation between $\left[\mathrm{SID}_{3}\right]$ and $\mathrm{pH}$ in healthy, experimentally dehydrated and diarrheic calves was previously observed (Constable et al., 2005b; Bachmann et al., 2012; Kirchner et al., 2014).
Perhaps the effects of decreased $\left[\mathrm{SID}_{3}\right]$ were masked by effects of D-lactate, $\mathrm{pCO}_{2}$, and $\left[\mathrm{A}_{\text {tot }}\right]$ on $\mathrm{pH}$, whereas, in one calf, low $\left[\mathrm{SID}_{3}\right]$ could be identified as the reason for low $\mathrm{pH}$ values.

D-Lactate caused metabolic acidosis in 2 of 3 acidotic calves and showed the highest correlation of all acid-base parameters with $\mathrm{pH}$. D-Lactic acidosis is very common in diarrheic calves (Omole et al., 2001). Most of the clinical symptoms, such as impaired suckle and palpebral reflex, somnolence, and staggering gait, which were formerly attributed to a decrease in blood $\mathrm{pH}$, were specifically due to hyper-D-lactatemia (Lorenz, 2009). However, we did not observe any of these symptoms in calves during our experiments. Ewaschuk et al. (2005) hypothesized that unhydrolyzed or unabsorbed milk lactose and other substrates fermented in the colon are responsible for the D-lactic acidosis associated with diarrheic calves. Our results do not dispute this hypothesis because pretreatment with milk-ORS resulted in higher baseline D-lactate. However, also in the group of water-ORS calves, the recognized acidosis was due to D-lactate and we observed a decrease of D-lactate after feeding milk-ORS. Rehydration and supply of buffer substances (i.e., ORS with high $\mathrm{SID}_{3}$ values) are usually successful in treating D-lactic acidosis in diarrheic calves (Lorenz and Vogt, 2006). Nevertheless, the effects on milk-ORS and water-ORS feeding on plasma levels of D-lactate should be analyzed in future studies, including a higher number of calves with diarrhea.

\section{CONCLUSIONS}

After a fasting period, plasma volume increased more quickly and to a greater extent after feeding water-ORS to diarrheic calves compared with feeding either milk or milk-ORS. Thus, water-ORS should be administered before milk or milk-ORS to improve fluid status in a more rapid and distinct manner. Nevertheless, diarrheic calves need milk to fulfill their energy needs. As milk has no alkalinizing abilities and contains less sodium, the administration of milk-ORS with provision of freechoice water is more advisable than feeding milk exclusively to correct diarrheal acidosis and hyponatremia. However, to prevent acute hypernatremia, milk-ORS feeding strictly requires free water access. Moreover, the effects of milk-ORS feeding on D-lactate levels in diarrheic calves need further elucidation. We used diarrheic but pretreated calves in our study; therefore, our recommendations for ORS management are speculative regarding treatment of calves on their first diarrheic day. Furthermore, the diarrhea of all calves was due to Cryptosporidium parvum, and whether these results are transferable to calves infected with other pathogens remains unclear. 


\section{ACKNOWLEDGMENTS}

This project was financially supported by DFG (BA 4400/1-1, Bonn, Germany). The authors thank the Department of Animal Production of the Saxon State Office for Environment, Agriculture and Geology in Köllitsch (Germany), under the direction of Uwe Bergfeld, and the farm for teaching and research in Köllitsch (Germany), under the direction of Wolfram Kunze, and its employees who were involved in conducting the experiments. Moreover, the authors thank Katherine Marie Kennedy [Leibniz Institute for Farm Animal Biology (FBN), Dummerstorf, Germany] for linguistic revision of the manuscript. The authors have not stated any conflicts of interest.

\section{REFERENCES}

Azizzadeh, M., H. F. Shooroki, A. S. Kamalabadi, and M. A. Stevenson. 2012. Factors affecting calf mortality in Iranian Holstein dairy herds. Prev. Vet. Med. 104:335-340. https://doi.org/10.1016/j .prevetmed.2011.12.007.

Bachmann, L., J. Berchtold, C. Siegling-Vlitakis, A. Willing, E. Radtke, and H. Hartmann. 2009a. Stewart-Variablen des SäurenBasen-Status bei Kälbern. [Stewart variables of the acid-base status in calves. Age related behaviour and influence of spontaneously occurring diarrhea.] Tierarztl. Prax. Ausg. G Grosstiere Nutztiere 37:365-374. https://doi.org/10.1055/s-0038-1623834.

Bachmann, L., T. Homeier, S. Arlt, M. Brueckner, H. Rawel, C. Deiner, and H. Hartmann. 2009b. Influence of different oral rehydration solutions on abomasal conditions and the acid-base status of suckling calves. J. Dairy Sci. 92:1649-1659. https://doi.org/10 $.3168 /$ jds.2008-1487.

Bachmann, L., B. Schmidt, U. Rauwolf, J. Wenge, and M. Coenen. 2012. Change of plasma volume, osmolality, and acid-base status in healthy calves after feeding of milk and water- and milk-based oral rehydration solutions. J. Dairy Sci. 95:6006-6014. https://doi .org/10.3168/jds.2012-5562.

Bell, F. R., and S. A. Razig. 1973. Gastric emptying and secretion in the milk-fed calf. J. Physiol. 228:499-512. https://doi.org/10 .1113/jphysiol.1973.sp010096.

Berchtold, J., H. Hartmann, and W. Hofmann. 2000. Bedeutung respiratorischer Kompensationsvorgange bei Azidosen des Kalbes. Dtsch. Tierarztl. Wochenschr. 107:10-16.

Constable, P. D., A. F. Ahmed, and N. A. Misk. 2005a. Effect of suckling cow's milk or milk replacer on abomasal luminal $\mathrm{pH}$ in dairy calves. J. Vet. Intern. Med. 19:97-102. https://doi.org/10.1111/j .1939-1676.2005.tb02665.x.

Constable, P. D., W. Grünberg, and L. Carstensen. 2009. Comparative effects of two oral rehydration solutions on milk clotting, abomasal luminal $\mathrm{pH}$, and abomasal emptying rate in suckling calves. J. Dairy Sci. 92:296-312. https://doi.org/10.3168/jds.2008-1462.

Constable, P. D., H. R. Staempfli, H. Navetat, J. Berchtold, and F. Schelcher. 2005b. Use of a quantitative strong ion approach to determine the mechanism for acid-base abnormalities in sick calves with or without diarrhea. J. Vet. Intern. Med. 19:581-589.

Doré, V., D. M. Foster, H. Ru, and G. W. Smith. 2019. Comparison of oral, intravenous, and subcutaneous fluid therapy for resuscitation of calves with diarrhea. J. Dairy Sci. 102:11337-11348. https://doi .org/10.3168/jds.2019-16970.

Ewaschuk, J. B., J. M. Naylor, and G. A. Zello. 2005. D-lactate in human and ruminant metabolism. J. Nutr. 135:1619-1625. https:// doi.org/10.1093/jn/135.7.1619.

Fassisi. 2020. Fassisi BoDia for cattle. Assessed May 13, 2020. https:/ /en.fassisi.de/products/livestock/cattle-bodia/.
Fayet, J. C. 1971. Plasma and faecal osmolality, water kinetics and body fluid compartments in neonatal calves with diarrhoea. Br. Vet. J. 127:37-44. https://doi.org/10.1016/S0007-1935(17)37787 -4 .

Gaucheron, F. 2005. The minerals of milk. Reprod. Nutr. Dev. 45:473483.

Goodell, G. M., J. Campbell, L. Hoejvang-Nielsen, W. Stansen, and P. D. Constable. 2012. An alkalinizing oral rehydration solution containing lecithin-coated citrus fiber is superior to a nonalkalinizing solution in treating 360 calves with naturally acquired diarrhea. J. Dairy Sci. 95:6677-6686. https://doi.org/10.3168/jds.2012-5605.

Groutides, C. P., and A. R. Michell. 1990. Intravenous solutions for fluid therapy in calf diarrhea. Res. Vet. Sci. 49:292-297. https:// doi.org/10.1016/0034-5288(90)90062-9.

Hartmann, H., J. Berchtold, and W. Hofmann. 1997. Pathophysiological aspects of acidosis in diarrhoeic calves. Tierarztl. Umsch. 52:568-574.

Hartmann, H., H. Meyer, G. Steinbach, N. Rossow, and R. Lesche. 1983. Effects of diarrhea on electrolyte level and osmolality in calf blood. Monatsh. Veterinarmed. 38:292-296.

Heine, J. 1982. Eine einfache Nachweismethode für Kryptosporidien im Kot. Zentralbl. Veterinarmed. B. 29:324-327. https://doi.org/ 10.1111/j.1439-0450.1982.tb01233.x.

Hildebrandt, T., E. Scheuch, W. Weitschies, M. Grimm, F. Schneider, L. Bachmann, and I. Vervuert. 2017. Measurement of abomasal conditions ( $\mathrm{pH}$, pressure and temperature) in healthy and diarrheic dairy calves using a wireless ambulatory capsule. Livest. Sci. 203:41-47. https://doi.org/10.1016/j.livsci.2017.06.011.

Jones, R., R. W. Phillips, and J. L. Cleek. 1984. Hyperosmotic oral replacement fluid for diarrheic calves. J. Am. Vet. Med. Assoc. 184:1501-1505.

Kirchner, D., L. Schwedhelm, M. Coenen, and L. Bachmann. 2014. Dietary influences on the hydration and acid-base status of experimentally dehydrated dairy calves. Vet. J. 199:251-257. https://doi .org/10.1016/j.tvjl.2013.11.007.

Kirchner, D., L. Schwedhelm, J. Wenge, I. Steinhöfel, C. Heinrich, M. Coenen, and L. Bachmann. 2015. Ultrasonographic imaging of abomasal milk clotting and abomasal diameter in healthy and diarrheic calves. Anim. Sci. J. 86:929-936. https://doi.org/10.1111/ asj.12382.

Levy, M., A. M. Merritt, and L. C. Levy. 1990. Comparison of the effects of an isosmolar and hyperosmolar oral rehydrating solution on the hydration status, glycemia and ileal content composition of healthy neonatal calves. Cornell Vet. 80:143-151.

Lorenz, I. 2009. D-Lactic acidosis in calves. Vet. J. 179:197-203. https: //doi.org/10.1016/j.tvj1.2007.08.028.

Lorenz, I., and S. Vogt. 2006. Investigations on the association of D-lactate blood concentrations with the outcome of therapy of acidosis, and with posture and demeanour in young calves with diarrhoea. J. Vet. Med. A Physiol. Pathol. Clin. Med. 53:490-494. https://doi.org/10.1111/j.1439-0442.2006.00863.x.

Moritz, A., ed. 2013. Klinische Labordiagnostik in der Tiermedizin. Schattauer Verlag, Stuttgart, Germany.

Naylor, J. M. 1992. Effects of electrolyte solutions for oral administration on clotting of milk. J. Am. Vet. Med. Assoc. 201:1026-1029.

Nouri, M., and P. D. Constable. 2006. Comparison of two oral electrolyte solutions and route of administration on the abomasal emptying rate of Holstein-Friesian calves. J. Vet. Intern. Med. 20:620626. https://doi.org/10.1111/j.1939-1676.2006.tb02906.x.

Olson, A., W. M. Sischo, A. C. B. Berge, A. Adams-Progar, and D. A. Moore. 2019. A retrospective cohort study comparing dairy calf treatment decisions by farm personnel with veterinary observations of clinical signs. J. Dairy Sci. 102:6391-6403. https://doi .org/10.3168/jds.2018-15623.

Omole, O. O., G. Nappert, J. M. Naylor, and G. A. Zello. 2001. Both L- and D-lactate contribute to metabolic acidosis in diarrheic calves. J. Nutr. 131:2128-2131. https://doi.org/10.1093/jn/131.8 .2128 .

Petit, H. V., M. Ivan, and G. J. Brisson. 1987. Duodenal flow of digesta in preruminant calves fed clotting or nonclotting milk replac- 
er. J. Dairy Sci. 70:2570-2576. https://doi.org/10.3168/jds.S0022 -0302(87)80326-0.

Rademacher, G., I. Lorenz, and W. Klee. 2002. Tränkung und Behandlung von Kälbern mit Neugeborenendurchfall. Tierarztl. Umsch. 57:177-189.

Sayers, R. G., A. Kennedy, L. Krump, G. P. Sayers, and E. Kennedy. 2016. An observational study using blood gas analysis to assess neonatal calf diarrhea and subsequent recovery with a European Commission-compliant oral electrolyte solution. J. Dairy Sci. 99:4647-4655. https://doi.org/10.3168/jds.2015-10600.

Sen, I., V. Altunok, M. Ok, A. Coskun, and P. D. Constable. 2009. Efficacy of oral rehydration therapy solutions containing sodium bicarbonate or sodium acetate for treatment of calves with naturally acquired diarrhea, moderate dehydration and strong ion acidosis. J. Am. Vet. Med. Assoc. 234:926-934. https://doi.org/10.2460/ javma.234.7.926.

Sen, I., P. D. Constable, and T. S. Marshall. 2006. Effect of suckling isotonic or hypertonic solutions of sodium bicarbonate or glucose on abomasal emptying rate in calves. Am. J. Vet. Res. 67:13771384. https://doi.org/10.2460/ajvr.67.8.1377.

Taylor, J. D., M. Rodenburg, and T. A. Snider. 2017. Comparison of a commercially available oral nutritional supplement and intravenous fluid therapy for dehydration in dairy calves. J. Dairy Sci. 100:4839-4846. https://doi.org/10.3168/jds.2016-12198.

Thomson, S., C. A. Hamilton, J. C. Hope, F. Katzer, N. A. Mabbott, L. J. Morrison, and E. A. Innes. 2017. Bovine cryptosporidiosis: impact, host-parasite interaction and control strategies. Vet. Res. 48:42. https://doi.org/10.1186/s13567-017-0447-0.
Thornton, S. N. 2010. Thirst and hydration: Physiology and consequences of dysfunction. Physiol. Behav. 100:15-21. https://doi .org/10.1016/j.physbeh.2010.02.026.

Torsein, M., A. Lindberg, C. H. Sandgren, K. P. Waller, M. Tornquist, and C. Svensson. 2011. Risk factors for calf mortality in large Swedish dairy herds. Prev. Vet. Med. 99:136-147. https://doi.org/ 10.1016/j.prevetmed.2010.12.001.

Trefz, F. M., I. Lorenz, A. Lorch, and P. D. Constable. 2017. Clinical signs, profound acidemia, hypoglycemia, and hypernatremia are predictive of mortality in 1,400 critically ill neonatal calves with diarrhea. PLoS One 12:e0182938. https://doi.org/10.1371/journal .pone.0182938.

USDA. 2014. Dairy 2014 Health and Management Practices on U.S Dairy Operations. National Anima Health Monitoring System, Animal and Plant Health Inspection Service, Fort Collins, CO.

Van Beaumont, W., J. E. Greenleaf, and L. Juhos. 1972. Disproportional changes in hematocrit, plasma volume, and proteins during exercise and bed rest. J. Appl. Physiol. 33:55-61. https://doi.org/ 10.1152/jappl.1972.33.1.55.

Wenge, J., I. Steinhöfel, C. Heinrich, M. Coenen, and L. Bachmann. 2014. Water and concentrate intake, weight gain and duration of diarrhea in young suckling calves on different diets. Livest. Sci. 159:133-140. https://doi.org/10.1016/j.livsci.2013.11.004.

Wittek, T., P. D. Constable, T. S. Marshall, and S. S. Crochik. 2005 Ultrasonographic measurement of abomasal volume, location, and emptying rate in calves. Am. J. Vet. Res. 66:537-544. https://doi .org/10.2460/ajvr.2005.66.537. 